\title{
Food Habits of the Collared Peccary on South Texas Rangelands
}

\author{
J.H. EVERITT, C.L. GONZALEZ, M.A. ALANIZ, AND G.V. LATIGo
}

\section{Abstract}

The food habits of the collared peccary (Pecari tajacu) were determined from three locations in south Texas. From September 1976 through August 1978, peccaries' food preferences on the Zachry Ranch in Jim Hogg and Zapata Counties were $74.7 \%$ cacti, $15.3 \%$ woody plants, $5.1 \%$ forbs, $2.3 \%$ grasses, $2.3 \%$ unknown plants, and $0.3 \%$ animal matter. Pricklypear pads comprised the bulk of the diet from October through March, whereas pricklypear fruit and mesquite pods were the most important foods from April through September. During the fall and early winter period, peccaries' food preferences were determined on the Gonzalez Ranch in Starr County and the Yturria Ranch in Kenedy and Willacy Counties. Food preferences on the Gonzalez Ranch were $81.5 \%$ cacti, $13.6 \%$ forbs, $2.0 \%$ woody plants, $0.6 \%$ grasses, $2.3 \%$ unknown plants, and $0.1 \%$ animal matter, whereas food preferences on the Yturria Ranch were $48.1 \%$ forbs, $32.5 \%$ cacti, $8.3 \%$ woody plants, $5.7 \%$ grasses, $5.3 \%$ unknown plants, and $0.1 \%$ animal matter. Pricklypear had a relatively low density on the Yturria Ranch in comparison with higher densities on the Zachry and Gonzalez Ranches. This study indicated that pricklypear was the preferred food of peccaries in south Texas, but in areas of low pricklypear density, forbs are highly utilized.

The collared peccary is abundant on many south Texas rangelands, but hunters and landowners neglect it as a game animal in Texas. With increased public demand for hunting on private lands in Texas, the economic benefit of the collared peccary to ranchers also increases. Therefore, there is a need to determine their food requirements so that proper habitat improvement programs can be initiated.

The objectives of this study were (1) to determine seasonal food preferences of peccaries in Jim Hogg and Zapata Counties and (2) to determine the fall and early winter diets of peccaries in Starr, Kenedy, and Willacy Counties.

Authors are range scientists, biological technician, and biological aid, respectively, Science and Education Administration, Agricultural Research, U.S. Department of Agriculture, Weslaco, Texas 78596

This study is a contribution from Soil and Water Conservation Research, Southern Region, Science and Education Administration, Agricultural Research, U.S. Dep. Agr., Weslaco, Texas.

The authors thank Zachry, Gonzalez, and Yturria Ranch personnel for their support and cooperation during this study.

Manuscript received August 17, 1979.

\section{Study Area}

Research was conducted on three ranches in south Texas: (1) the H.B. Zachry Randado Ranch, $44 \mathrm{~km}$ southwest of Hebbronville and $40 \mathrm{~km}$ northeast of Zapata in Jim Hogg and Zapata Counties;

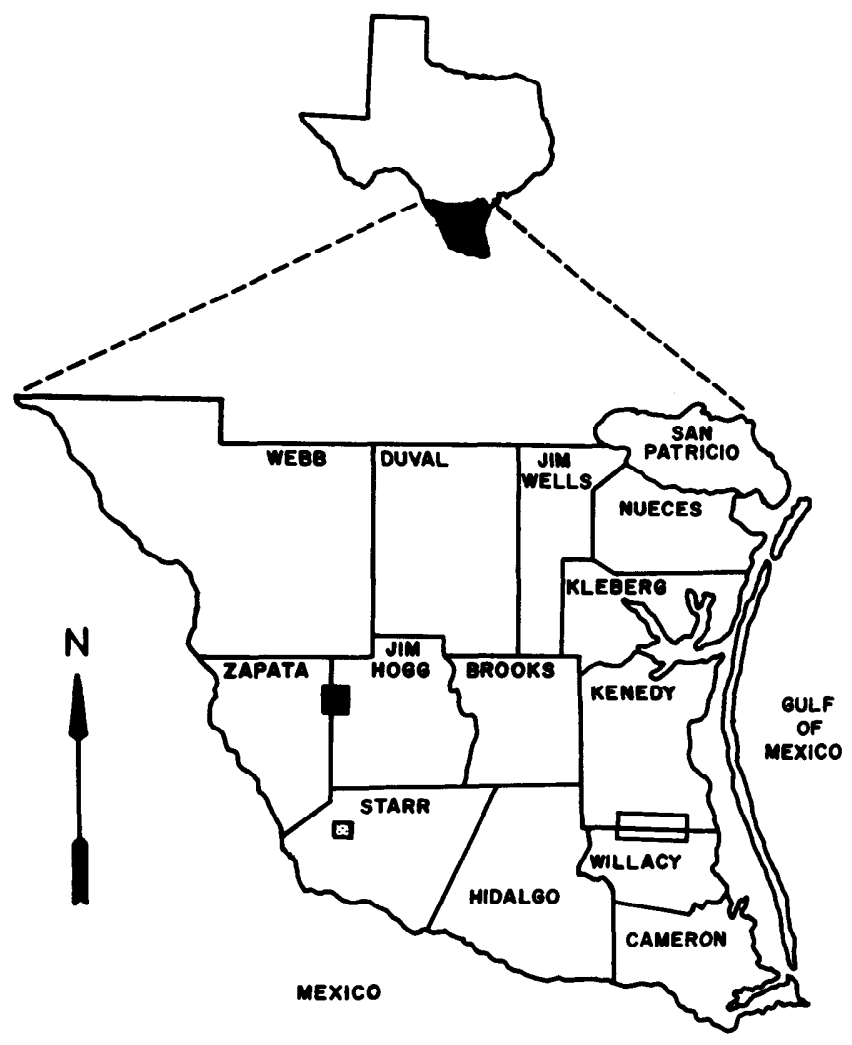

ZACHRY RANCH

oOnzalez RANCH

YTURRIA RANCH

Fig. 1. Locations of study areas in south Texas. 
(2) the Gonzalez Ranch, $24 \mathrm{~km}$ northwest of Rio Grande City in Starr County; (3) the Yturria Ranch, $13 \mathrm{~km}$ north of Raymondville in Willacy and Kenedy Counties (Fig. 1). The Zachry and Gonzalez Ranches are in the South Texas Plains vegetation region, whereas the Yturria Ranch is in a transitional zone between the Texas Coastal Prairies and the South Texas Plains Vegetational regions (Gould 1975).

South Texas winters are short and temperatures relatively warm throughout the year. The average growing season exceeds 300 days (U.S. Dept. Commerce 1970). Long-term average annual rainfall is 53,44 , and $68 \mathrm{~cm}$, for the Zachry, Gonzalez, and Yturria Ranches, respectively. Soils on all three study areas are primarily sandy loams. Major land use on all of the study areas is cattle ranching, primarily cow-calf operations, and peccaries are common on all areas. Some work indicates that peccary density might be about 1 per 15 ha on the Zachry Ranch. No estimates of peccary density were available for the Gonzalez and Yturria Ranches.

The Zachry Ranch has 3,045 ha of rolling brushland intersected by caliche hills and gulleys. Higginbotham (1975) described the vegetation of the Zachry Ranch. Mechanical and chemical brush control were practiced to control honey mesquite (Prosopis glandulosa) and goldenweed (Isocoma coronopifolia), respectively (Brothers 1979). Small areas were rootplowed or bulldozed and terraced in strips, and seeded to buffelgrass (Cenchrus ciliaris).

The Gonzalez Ranch has 680 ha of native and improved rangeland. Topography, vegetation, and soils are similar to those of the Zachry Ranch. About 50\% of the native rangeland has been rootplowed and seeded to buffelgrass.

The Yturria Ranch has 7,200 ha of native and improved rangeland. Topography is flat to gently sloping. Most of the area is made up of Chaparral-mixed grass communities (Drawe et al. 1978). Lagunas make up 3 to $5 \%$ of the area. Lagunas support a variety of grasses, sedges, and forbs. Several small tracts of brushland were bulld ozed or rootplowed on the ranch, allowing native grasses and herbs to become reestablished, and buffelgrass was seeded to some of these areas.

\section{Materials and Methods}

Food habits were measured by stomach analyses on 115 peccaries that were collected from the three study areas. Forty-five peccarics were collected from the Zachry Ranch from September 1976 to August 1978. Normally two peccaries were shot each month; however, numbers varied from one to three each month during the 2-year study. A total of 70 peccaries were collected at 1- to 3-week intervals during the annual hunting season from October 1 to early
January from the Gonzalez and Yturria Ranches. These animals were killed by hunters. Of these, 35 were collected from the Gonzalez Ranch from 1975 to 1978 . Thirty-five animals were collected from the Yturria Ranch in 1975 and 1976.

After a peccary was killed, the entire stomach was removed and about a liter of the contents was saved. Samples were preserved in $10 \%$ formalin and later analyzed for composition by the point frame method (Chamrad and Box 1964). Stomach contents were grouped into six classes: cacti, forbs, grasses, woody plants, animal matter, and unknown plant material. All data reported are averages for the category indicated.

The density and species composition of woody plants and cacti were determined by the point-centered quarter method (Dix 1961) to determine relative availability of important plants for peccary diets.

Data were subjected to variance analysis. All statistical comparisons were tested at the $p \leq 0.05$ level (Steel and Torrie 1960).

\section{Results and Discussion}

The annual average diet of peccaries from the Zachry Ranch was made up of $74.7 \%$ cacti, $15.3 \%$ woody plants, $5.1 \%$ forbs, $2.3 \%$ grasses, $2.3 \%$ unknown plants, and $0.3 \%$ animal matter. The percentage of cacti was significantly higher than any other class. Twenty-five food items were identified in the diet, including 23 plant taxa ( 1 cacti, 9 woody plants, 11 forbs, and 2 grasses) and two types of unidentified animal matter.

The fall and early winter peccaries' diets from the Gonzalez and Yturria Ranches, respectively, were 81.5 and $32.5 \%$ cacti, 13.6 and $48.1 \%$ forbs, 2.0 and $8.3 \%$ woody plants, 0.6 and $5.7 \%$ grasses, 2.3 and $5.3 \%$ unknown plants, and 0.1 and $0.1 \%$ animal matter. The percentage of cacti was significantly higher than any other class on the Gonzalez Ranch, whereas on the Yturria Ranch, the percentage of forbs was significantly higher than any other class. Thirteen plant taxa were identified in the diet on the Gonzalez Ranch: 2 cacti, 5 woody plants, 5 forbs, and 1 grass. On the Yturria Ranch, 25 plant taxa were identified in the diet including 2 cacti, 13 forbs, 6 woody plants, and 4 grasses.

The two most important plants in the peccaries'annual diet from the Zachry Ranch were pricklypear cactus (Opuntia lindheimeri) and honey mesquite pods (Table 1). These two plants made up $86.3 \%$ of the diet. Both pricklypear pads and fruit were eaten. Peccary diets were influenced by the periods of availability of pricklypear fruit and mesquite pods (Fig. 2). Pricklypear pads were the bulk of the diet from October through March; however, with the onset of flowering and setting of young pricklypear fruit in

Table 1. Frequency of occurrence and volume of major foods $\geq 1 \%$ volume) in the year-round diet of peccaries on the Zachry $R$ anch and fall and early winter diets of peccaries on the Gonzalez and Yturria Ranches in south Texas.

\begin{tabular}{|c|c|c|c|c|c|c|}
\hline \multirow[b]{2}{*}{ Major forage types } & \multicolumn{2}{|c|}{ Zachry Ranch $(n=45)$} & \multicolumn{2}{|c|}{ Gonzalez Ranch $(n=35)$} & \multicolumn{2}{|c|}{ Yturria Ranch $(n=35)$} \\
\hline & $\begin{array}{c}\text { Frequency } \\
(\%)\end{array}$ & $\begin{array}{c}\text { Volume } \\
(\%)\end{array}$ & $\begin{array}{c}\text { Frequency } \\
(\%)\end{array}$ & $\begin{array}{c}\text { Volume } \\
(\%)\end{array}$ & $\begin{array}{c}\text { Frequency } \\
(\%)\end{array}$ & $\begin{array}{c}\text { Volume } \\
(\%)\end{array}$ \\
\hline Opuntia lindheimeri-vegetative & 80.0 & 47.3 & 100.0 & 81.4 & 91.4 & 31.9 \\
\hline O. lindheimeri-fruit & 48.9 & 27.4 & & & & \\
\hline Prosopis glandulosa-pods & 26.7 & 11.6 & & & & \\
\hline Yucca treculeana & 33.3 & 3.0 & & & 25.7 & 5.7 \\
\hline Solanum triquetrum & 22.2 & 1.3 & 45.7 & 2.6 & & \\
\hline Physalis viscosa & 20.0 & 1.2 & & & & \\
\hline Jatropha cathartica & & & 40.0 & 6.7 & & \\
\hline Rivina humilis & & & 34.3 & 1.8 & & \\
\hline Pithecellobium flexicaule-pods & & & 11.4 & 1.4 & 8.6 & 2.1 \\
\hline Portulaca mundula & & & & & 97.1 & 37.4 \\
\hline Phyla nodiflora & & & & & 31.4 & 3.4 \\
\hline P. incisa & & & & & 37.1 & 1.5 \\
\hline Enchinodorus rostratus & & & & & 20.0 & 2.7 \\
\hline
\end{tabular}

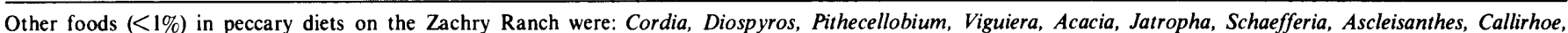

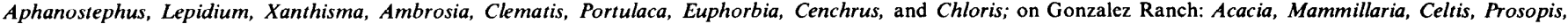

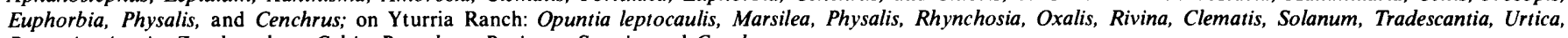
Prosopis, Acacia, Zanthoxylum, Celtis, Paspalum, Panicum, Setaria, and Cenchrus. 

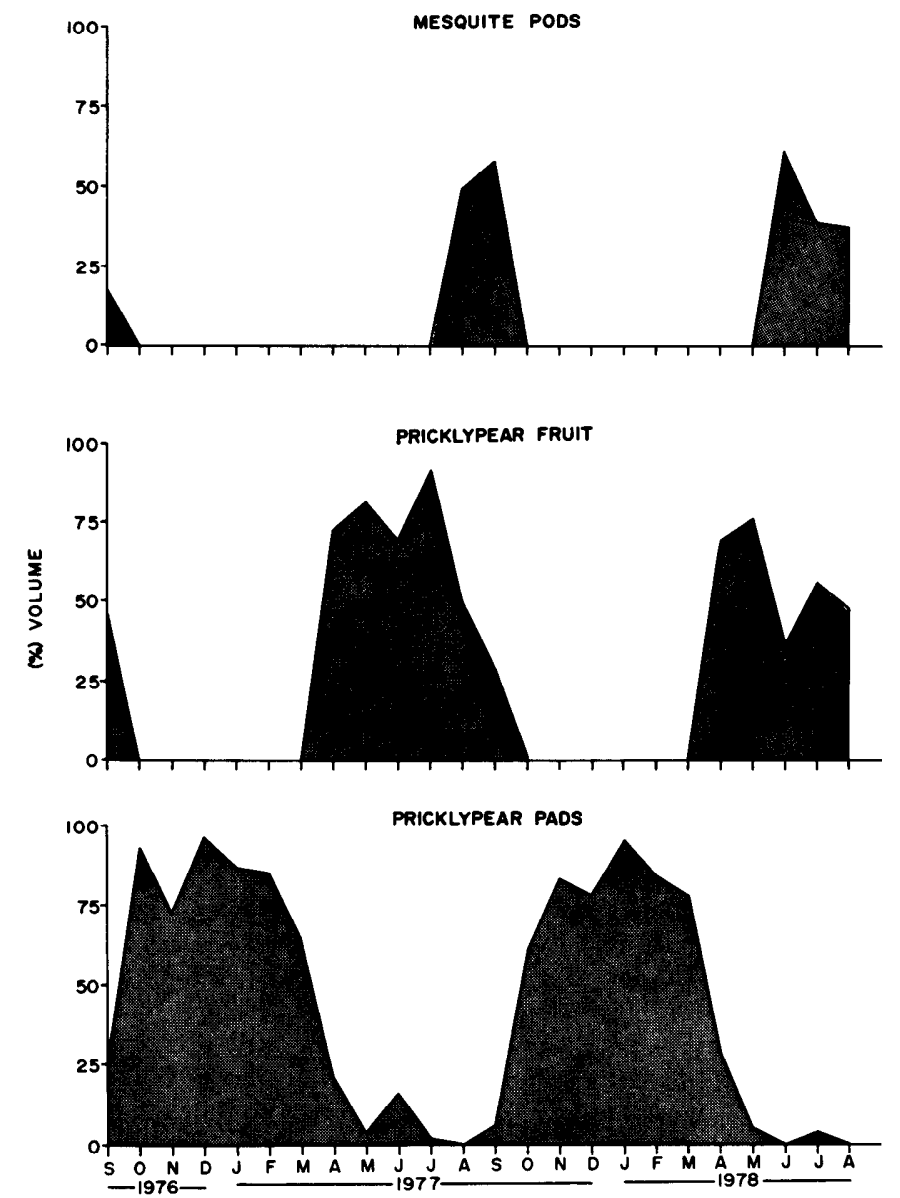

Fig. 2. Contributions of major foods to the seasonal diets of peccaries on the Zachry Ranch in south Texas.

April, the peccary diet shifted. Pricklypear fruit made up most of the diet from April until the mature mesquite pods began to drop to the ground in summer; then the diet consisted mainly of these two items. By October, pricklypear fruit and mesquite pods were depleted, and the peccaries shifted back to eating pricklypear pads.

Peccary foods preferred during the fall and early winter on the Gonzalez Ranch were similar to those on the Zachry Ranch during the same period-pricklypear pads made up most of the diet (Table 1). However, forbs were eaten in larger amounts. This was caused by the high use of Berlandier nettlesperge (Jatropha cathartica) roots.

Moss rose (Portulaca mundula) and pricklypear comprised $69.1 \%$ of the fall and early winter peccaries' diet on the Yturria Ranch. Both species had a greater than $90 \%$ frequency. Moss rose (an annual forb) is a frequently encountered species and often remains green through the mild winters in this area (Everitt and Gonzalez 1979). Important perennial forbs were: turkeytangle (Phyla nodiflora), frog-fruit (Phyla incisa), and burhead (Enchinodorus rostratus). These three species had a greater than $20.0 \%$ frequency and together contributed $7.6 \%$ to the diet. Spanish dagger (Yucca treculeana) bark was the most important woody plant consumed, and made up over $50 \%$ of the volume of each of two stomachs.

The relative densities of pricklypear and honey mesquite plants were high on the Zachry Ranch. Pricklypear averaged 473 plants/ha and made up $29.1 \%$ of the composition of the native sites; while on those sites disturbed by rootplowing and bulldozing, pricklypear averaged 638 plants / ha and comprised $38.2 \%$ of the composition. Honey mesquite averaged 190 plants/ha and its composition was $11.7 \%$ on the native sites; whereas, its density was 283 plants/ha or $16.9 \%$ of the plant composition on disturbed sites. However, only mesquite trees on native sites produced pods, since trees on the disturbed sites were immature. Mesquite pods were generally available and eaten from June through September (Fig. 2), except during 1977 when a late crop was available during August and September. The late mesquite crop in 1977 seemed to be the result of a wetter winter and spring during that year.

Pricklypear plants were also abundant on the Gonzalez Ranch, averaging 689 plants/ha and making up $13.0 \%$ of the species composition on the native sites. On disturbed sites, there were 1,032 pricklypear plants/ha and they made up $16.4 \%$ of the plant composition.

In contrast to the other ranches, pricklypear plants were relatively scarce on the Yturria Ranch. Native sites had only 54 pricklypear plants / ha and they averaged $0.9 \%$ of the species composition. On disturbed sites, 42 plants/ha occurred and it averaged $5.5 \%$ of the species composition. This low density may help account for its lower use in the peccaries' diet, although it was a highly preferred species and made up about one third of the diet.

Our data indicated that peccaries in south Texas prefer pricklypear cactus; however, if pricklypear was scarce, forbs were consumcd in larger quantities and made up the major portion of the diet. Both pricklypear pads and fruits were eaten. Pricklypear fruit and mesquite pods were important foods during the spring and summer, whereas pricklypear pads made up most of the fall and winter diets. Except for the high use of forbs on the Yturria Ranch, our results generally support those of Jennings and Harris (1953), who reported that pricklypear comprised $84 \%$ of peccary diets in south Texas. Eddy (1961) reported that forbs were heavily used for short times in Arizona; however, they were not important staple food items in peccaries'diets, but they were important supplements when other foods were absent. Our data indicated that peccary food preferences might compete with those of other south Texas wildlife. Several foods eaten by peccaries are also used by whitetailed deer (Odocoileus virginianus) and feral pigs (Sus scrofa) (Arnold and Drawe 1979; Everitt and Gonzalez 1979; Everitt and Alaniz 1980).

Well-managed areas wherc brush is mechanically controlled do not seem to destroy the peccaries' habitat and they benefit the peccaries' diet by providing higher densities of pricklypear and forbs than undisturbed areas (Gonzalez and Dodd 1979). Herbicides should be used ca refully for mesquite control, since mesquite pods are an important food for peccaries. Also, burning should be well managed so that pricklypear production will not be adversely affected (Bunting et al. 1980).

\section{Literature Cited}

Arnold, L.A., Jr., and D.L. Drawe. 1979. Seasonal food habits of whitetailed deer in the South Texas Plains. J. Range Manage. 32:175-178.

Brothers, A. 1979. One winning combination. Rangelands. 1:20-22.

Bunting, S.C., H.A. Wright, and L.F. Neuenschwander. 1980. Long-term effects of fire on cactus in the Southern Mixed Prairie of Texas. J. Range Manage. 33:85-88.

Chamrad, A.D., and T.W. Box. 1964. A point frame for sampling rumen contents. J. Wildl. Manage. 28:473-477.

Dix, R.L. 1961. An application of the point-centered quarter method to the sampling of grassland vegetation. J. Range Manage. 14:63-69.

Drawe, D.L., T.W. Box, and A.D. Chamrad. 1978. Plant communities of the Welder Wildlife Refuge. Contr. 5, Series B (revised). Welder Wildlife Found., Sinton, Texas. 28 p.

Eddy, T.A. 1961. Foods and feeding patterns of the collared peccary in southern Arizona. J. Wildl. Manage. 25:248-257.

Everitt, J.H., and M.A. Alaniz. 1980. Fall and winter diets of feral pigs in south Texas. J. Range Manage. 33:126-129.

Everitt, J.H., and C.L. Gonzalez. 1979. Botanical composition and nutrient content of fall and early winter diets of white-tailed deer in south Texas. Southwestern Natur. 24:297-310.

Gonzalez, C.L., and J.D. Dodd. 1979. Production response of native and introduced grasses to mechanical brush manipulation, seeding, and fertilization. J. Range Manage. 32:305-309.

Gould, F.W. 1975. Texas plants-a checklist and ecological summary. MP-585. Texas Agr. Exp. Sta., Texas A\&M Univ., College Station. 121 p. 
Higginbotham, 1. 1975. Composition and production of vegetation on the Zachry Ranch in the South Texas Plains. Unpub. M.S. Thesis. Texas A\&I Univ., Kingsville. 131 p.

Jennings, W.S., and J.T. Harris. 1953. The collared peccary in Texas. Texas Game and Fish Comm., Fed. Aid Rep. Ser. 10, Austin. 31 p.
Steel, R.G.D., and J.H. Torrie. 1960. Principles and Proced ures of Statistics. McGraw-Hill Book Co., Inc., New York. 481 p.

United States Department of Commerce. 1970. Climatological summary. Brownsville, Texas. $46 \mathrm{p}$. 